\title{
Assessment of Ovarian Follicles and Serum Reproductive Hormones in Molybdenum Trioxide Nanoparticles Treated Rats
}

\author{
Evaluación de Folículos Ováricos y Hormonas Reproductivas en Suero \\ de Ratas Tratatas con Nanopartículas de Trióxido de Molibdeno
}

Fardin Asadi'; Simin Fazelipour²; Reyhaneh Hooshmand Abbasi³; Mahsa Jahangirirad ${ }^{4}$; Zahra Tootian ${ }^{3}$; Keivan Nedaei $^{5}$ \& Mojan Fazelipour ${ }^{6}$

ASADI, F.; FAZELIPOUR, S.; ABBASI, R. H.; JAHANGIRIRAD, M.; TOOTIAN, Z.; NEDAEI, K. \& FAZELIPOUR, M. Assessment of ovarian follicles and serum reproductive hormones in molybdenum trioxide nanoparticles treated rats. Int. J. Morphol., 35(4):1473-1481, 2017.

SUMMARY: Special features of nanoparticles have resulted in their widespread use. Small molybdenum trioxide $\left(\mathrm{MoO}_{3}\right)$ nanoparticles can translocate from the entry portals into the circulatory and lymphatic systems and ultimately to body tissues and organs depending on their composition and size. In this research, sixty Wistar rats weighting 180-250 g were divided into 6 groups (n=10) randomly: Group 1 (Control) did not receive any medicine. Group 2 (Sham) received intraperitoneal normal saline for 35 days on a daily basis. Groups 3, 4, 5 and 6 received 50 , 100,200 , and $300 \mathrm{mg} / \mathrm{kg} \mathrm{MoO}$, respectively, the same way in the sham group and at the same interval. At the end of the experiment, the rats were weighted again and anesthetised. Then blood samples were taken from their hearts to determine the serum levels of estrogen, progesterone, and gonadotropins. Their ovaries were removed and ovarian volume, follicular diameter, number of each follicle type, and oocyte volume were determined. Results indicated that $\mathrm{MoO}_{3}$ nanoparticles strongly reduced body and ovarian weights in the rats. Moreover, a significant decrease was observed in ovarian volume, the number of follicle types, oocyte volume and follicular diameter. The nanoparticles increased the number of atretic follicles via ovarian tissue structure. $\mathrm{MoO}_{3}$ nanoparticles decreased serum estrogen level and increased serum level of FSH that was associated with disruption in the regulation of progesterone and $\mathrm{LH}$ secretion. The findings showed that $\mathrm{MoO}_{3}$ nanoparticles could bear negative effects on ovarian structure and function.

KEY WORDS: Molybdenum trioxide Nanoparticles; Ovary; Stereology; Reproductive hormones; Rats.

\section{INTRODUCTION}

Recently, the use of nanoparticles to replace normalscale particles has been increased rapidly. The smaller size and unique properties of the nanoparticles (NPs) has substantially improved the application of these pigments, though, it has also generated greater concern in term of risks to human health and the environment (Adams et al., 2006). Based on toxicological studies carried out in the last ten years, ultrafine particles $(\mathrm{d}<100 \mathrm{~nm})$ are known to cause serious problems in organs (Bakand \& Hayes, 2016). Nanoparticles (NPs) are frequently found commercially as cosmetics and sunscreens $\left(\mathrm{TiO}_{2}, \mathrm{Fe}_{3} \mathrm{O}_{4}\right.$, and $\left.\mathrm{ZnO}\right)$, fillers in dental fillings $\left(\mathrm{SiO}_{2}\right)$, in water filtration and catalytic systems, and in photovoltaic cells (CdS, $\mathrm{CdSe}, \mathrm{ZnS})$. Molybdenum trioxide $\left(\mathrm{MoO}_{3}\right)$ nanoparticles are widely used as a catalyst, cracking catalyst, hydrogenation catalyst, pigment, and in ceramics and glass production (Zollfrank et al., 2012). Because of its layered structure and the ease of the Mo (VI)/ Mo (V) coupling, $\mathrm{MoO}_{3}$ is of interest in electrochemical devices and displays. $\mathrm{MoO}_{3}$ has also been suggested as a potential anti-microbial agent, in polymers. In contact with water, it forms $\mathrm{H}+$ ions that can effectively kill bacteria (Ferreira et al., 2000).

The increasing public and occupational exposure to nanomaterials call for concern with respect to nontoxicity. The emergence of nanoparticles has added a new threat to

\footnotetext{
${ }^{1}$ Department of Pediatric, Mousavi Hospital, Zanjan University of Medical Science, Zanjan, Iran.

${ }^{2}$ Anatomy professor, Medical Sciences Branch, Islamic Azad University, Tehran, Iran.

${ }^{3}$ Department of Basic Sciences, Faculty of Veterinary Medicine, University of Tehran, Tehran, Iran.

${ }^{4}$ Water Purification Research Center, Medical Sciences Branch, Islamic Azad University, Tehran, Iran.

${ }^{5}$ Department of Medical Biotechnology and Nanotechnology, School of Medicine, Zanjan University of Medical Sciences, Zanjan, Iran.

${ }^{6}$ Bachelor of Science in Life Sciences, University of British Columbia
} 
the vulnerable female population. Normal female reproduction and foetal development are fundamental for the perpetuation of the species. The toxicity of nanoparticles to female reproductive and developmental health has been shown in various models (Shoults-Wilson et al., 2011). Owing to the fact that female gametes are rather limited compared to reproductive male gametes, the female reproductive system is substantially more fragile than other systems (Hillier, 1994). Periodic growth and regression of female reproductive organs, such as the ovary and uterus, is strictly regulated by hormones. Dynamic activity and accurate hormonal control makes this system more sensitive to foreign bodies and physiological stress compared to other physiological processes (Armenti et al., 2008). Moreover, the disturbance of female reproduction inescapably leads to abnormal foetal development. Many environmental chemicals including nanomaterials have already been demonstrated to bear harmful effects on the female reproductive system (Armenti et al.). The toxic effects of several nanomaterials such as fullerene, $\mathrm{TiO}_{2}$ and silver nanoparticles on female reproductive and developmental health has been reported recently (Tsuchiya et al., 1996; Armenti et al.; Wang et al., 2011).

Based on the fact that the gametes are limited in female mammals, formed in fetus periods and not being created in life time again, the present study was conducted to investigate the effects of these particles on ovaries. Accordingly, the effects of daily intraperitoneal exposure of $\mathrm{MoO}_{3}$ nanoparticles on ovaries of adult rats were examined in this study.
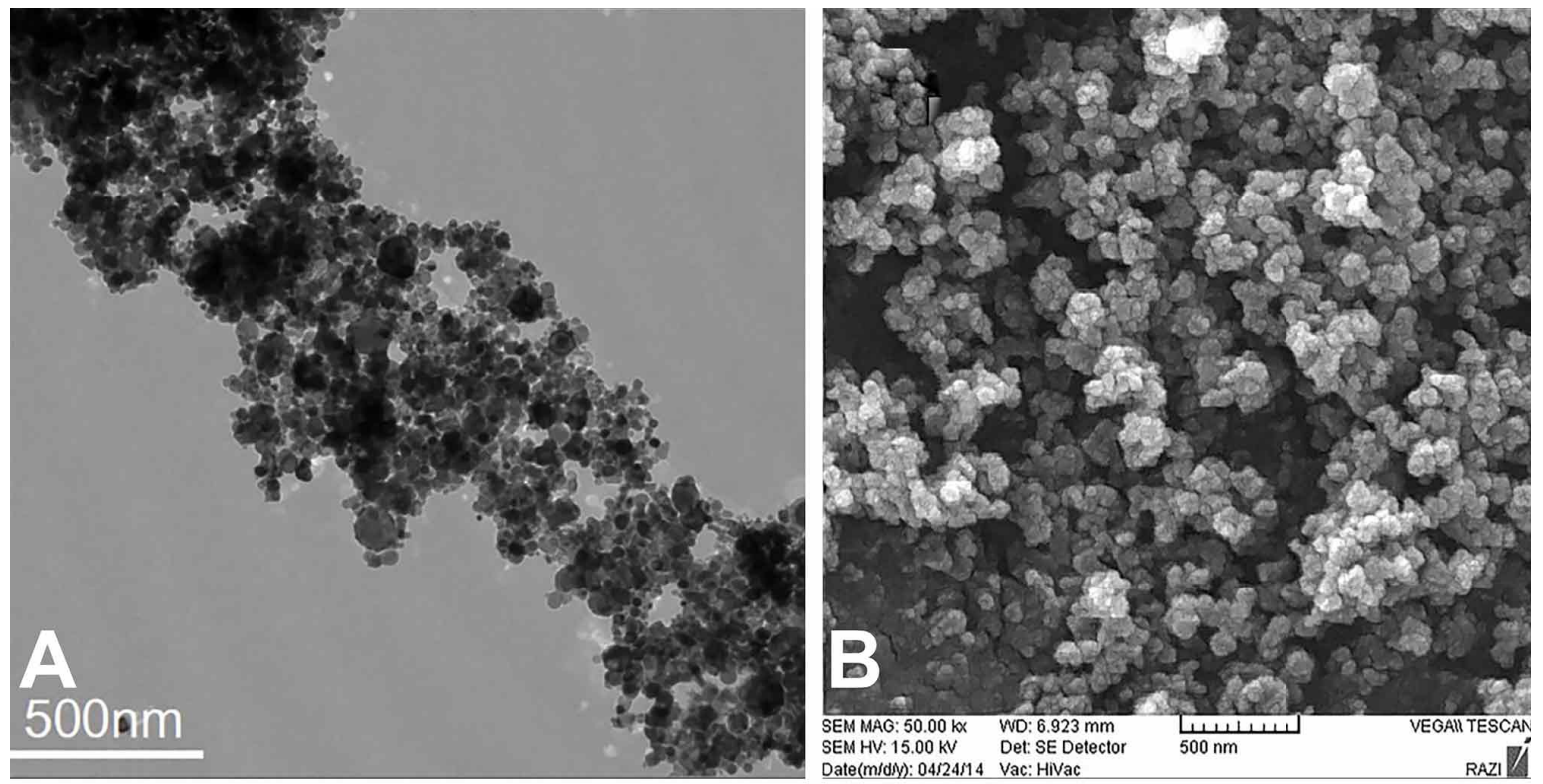

Molyb denum Oxide Nanoparticles / Nanopowders (MoO3) $13-80 \mathrm{~nm} 99.94 \%$

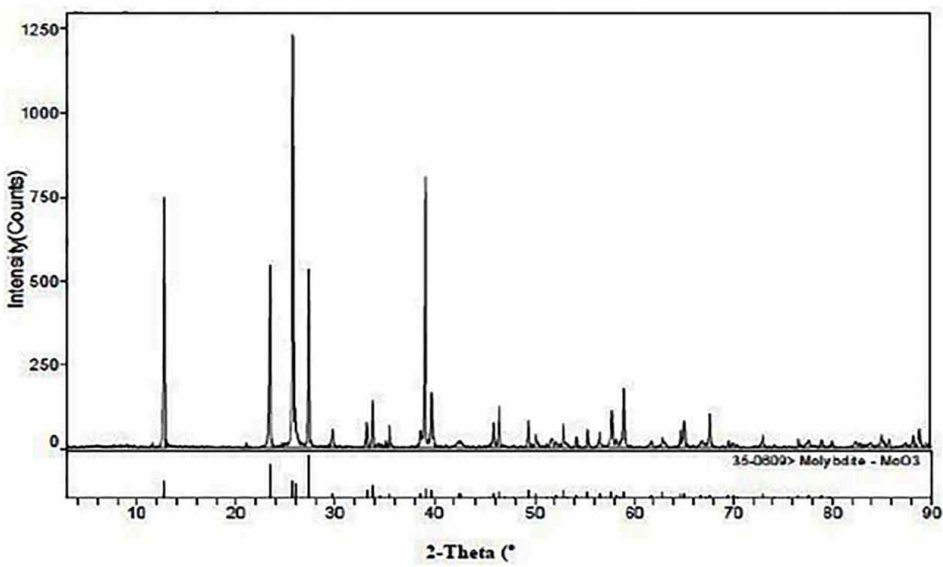

Fig. 1. (A) Transmission Electron Microscopy (TEM), (B) Scanning Electron Microscopy (SEM) and (C) XRD Pattern of $\mathrm{MoO}_{3}$ nanoparticles. 


\section{MATERIAL AND METHOD}

Molybdenum Oxide Nanoparticle. $\mathrm{MoO}_{3}$ nanoparticles $\left(\mathrm{MoO}_{3}, 99.94+\%\right.$, high purity, 13-80 nm, orthorhombic crystal) were purchased from Iranian nanomaterials pioneers company (Khorasan, Iran). The size and structure of the Molybdenum Oxide Nanoparticles were analysed by transmission electron microscopy (TEM) (LEO 912AB). X-ray diffraction (XRD) measurements were recorded using a Philips PW 1800 diffractometer. The particle size and morphology of the nanoparticles were examined using scanning electron microscope (SEM) (Fig. 1).

Animals and Conditions. 60 Adult Wistar female rats approximately 180-250 g were maintained under standard laboratory conditions. The rats were kept throughout the study on a $12 \mathrm{~h}$ light - dark cycle and room temperature of $22 \pm 2{ }^{\circ} \mathrm{C}$. All mice had ad libitum access to food and water. The investigations were conducted in accordance with the ethical principles of the use of laboratory animals adopted by Zanjan University of Medical Sciences. Sixty rats were randomized into six groups: did not receive any medicine. Group 2 (Sham) were received intraperitoneal normal saline for 35 days on a daily basis. The Groups 3, 4, 5 and 6 were received 50,100, 200, and $300 \mathrm{mg} / \mathrm{kg} \mathrm{MoO}_{3}$ the same way as the sham group and the same interval.

The stages of oestrus. Oestrous cycles were monitored taking daily vaginal smears. The rats were selected in prooestrus stage.

Hormonal analysis. At the end of the treatment period, animals were weighted (secondary weight after treatment). Gonadotropin, oestrogen and progesterone serum were assessed using the Chemiluminescence method.

Stereological methods. Serial sections were collected from ovary and isotropic uniform random (IUR) method was adopted for counting. Five micrometre-thick serial sections were used for ovary assessment. The sections were stained with Haematoxylin and eosin (Merck Company).

Estimation of the ovarian cortex and medulla volume $\left(\mathbf{m m}^{3}\right)$. To estimate the mean total volume of ovary, the images of $5 \mu \mathrm{m}$ semi-thick sections were prepared and counting probe was randomly superimposed on the images. Then the points were counted and the total volume of the ovary was estimated using the Cavalier methods.

Measurement of follicles diameters. To determine the diameter of different follicles, 12 sections were randomly selected and fields of view were examined. Some follicles with oocytes in the central part were selected and the follicle diameter on three sides (longitudinal, transverse and oblique) were analysed in different experimental groups using the Axiovision software.

Follicular counts. To count different types of follicles, 12 sections were randomly selected and used for follicular count. The nucleus in the selected follicles was in the counting frame and did not have contact with the left and lower side line. They were used to determine the number of different kinds of follicles.

Volume of oocytes $\left(\mu \mathrm{m}^{3}\right)$. Oocyte volume was measured using the Nucleator method. 12 sections were randomly selected from each sample and different follicles of each section were captured by a microscope equipped with a camera. Oocytes of follicles in each field of view were analysed from the middle of the oocyte nucleoli to the membrane with Axiovision software. If nucleoli were absent, measurements were taken from the centre of the nucleus to the oocyte membrane.

Statistical analysis. The statistical analyses were performed using SPSS (Version 19). The statistical evaluation included a two-tailed Student's t-test or analysis of variance (ANOVA) following multiple comparison tests using Duncan's method and/or Kruskal Wallis. All data are expressed as mean \pm SE. $\mathrm{P}<0.05$ was considered as significant level of statistical analysis.

\section{RESULTS}

Effects on body weight differences and ovary weights. The results showed that there was a significant dosedependent changes in the body weight compared to the Control and Sham groups, especially at dosages of 200,300 $\mathrm{mg} / \mathrm{kg}(\mathrm{P}<0.05)$ (Table I and Fig. 2). The effect of $\mathrm{MoO}_{3}$ nanoparticles on the ovary showed a significant decrease in the weights when compared to Control and Sham groups $(\mathrm{P}<0.05)$ (Table I).

Effects on ovary volume. As shown in Table II, the total volume of ovaries in $\mathrm{MoO}_{3}$ nanoparticle groups were decreased significantly $(200,300 \mathrm{mg} / \mathrm{kg})$ compared to the Control and Sham groups $(\mathrm{P}<0.05)$. A reduction in ovarian volume was related to the ovarian cortex because the main part of the ovary was cortex, which consisted of all follicles and most elements of the ovary (Table II).Ovarian medulla in some of experimental groups showed no significant changes compared to the Control group ( $\mathrm{P}>0.05)$. 
Table I. Mean body weight differences and ovary weights in rats after 35 days intraperitoneal (IP) administration of $\mathrm{MoO}_{3}$ nanoparticles $($ mean \pm S.D)

\begin{tabular}{lcccrcr}
\hline & Control & Sham & $50 \mathrm{mg} / \mathrm{kg}$ & $100 \mathrm{mg} / \mathrm{kg}$ & $200 \mathrm{mg} / \mathrm{kg}$ & $300 \mathrm{mg} / \mathrm{kg}$ \\
\hline Primary body weight $(\mathrm{g})$ & $235 \pm 19.68$ & $201 \pm 6.51$ & $203.66 \pm 9.83$ & $215 \pm 24.08$ & $205.75 \pm 23.65$ & $209.16 \pm 11.58$ \\
Secondary body weight $(\mathrm{g})$ & $244.16 \pm 20.35$ & $216.66 \pm 6.83$ & $194 \pm 13.87$ & $209.16 \pm 29.15$ & $161.66 \pm 31.25$ & $183 \pm 9.83$ \\
Body weight differences $(\mathrm{g})$ & $9.16 \pm 1.26^{\mathrm{a}}$ & $13.6 \pm 0.8 \mathrm{a}$ & $-9 \pm 3^{\mathrm{b}}$ & $-6 \pm 5.07^{\mathrm{b}}$ & $-44 \pm 7.6^{\mathrm{c}}$ & $-26 \pm 1.75 \mathrm{~d}$ \\
Ovary weight (g) & $0.075 \pm 0.0054^{\mathrm{a}}$ & $0.068 \pm 0.007^{\mathrm{a}}$ & $0.046 \pm 0.008^{\mathrm{b}}$ & $0.048 \pm 0.007^{\mathrm{b}}$ & $0.04 \pm 0.01^{\mathrm{b}}$ & $0.03 \pm 0.005^{\mathrm{b}}$ \\
\hline
\end{tabular}

The disparate letters show significant differences $(\mathrm{P}<0.05)$

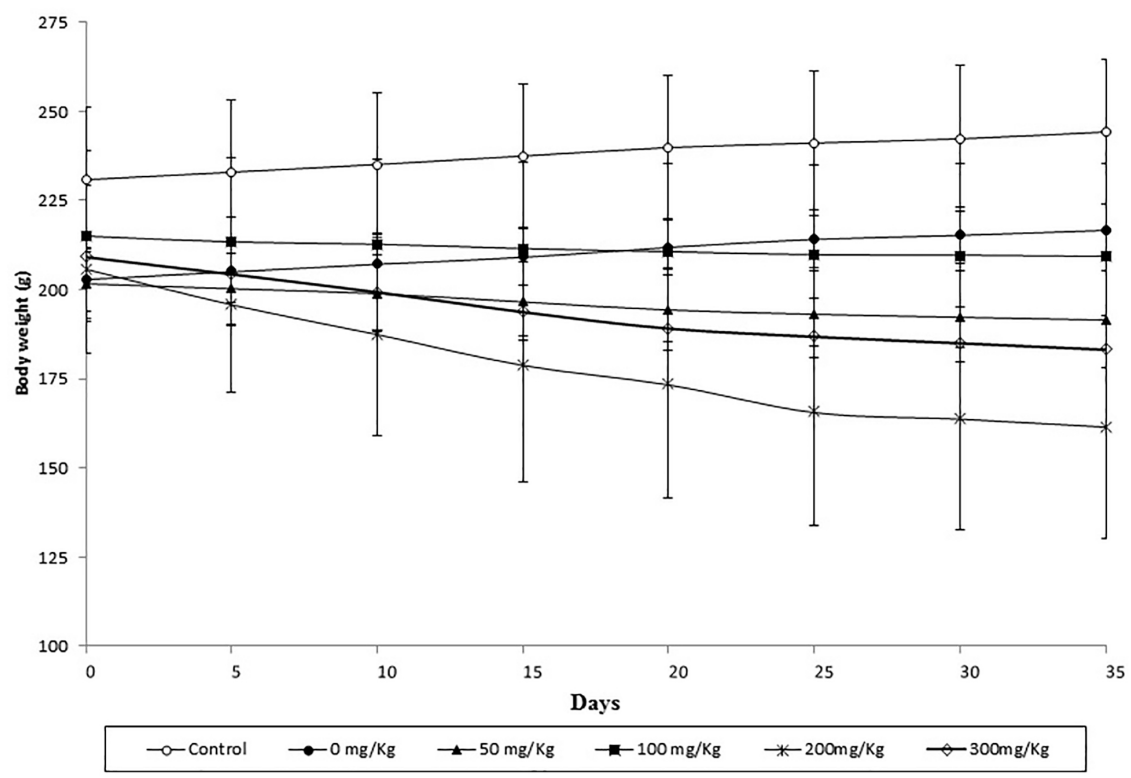

Fig. 2. Body weight changes during 35-days administration of $\mathrm{MoO}_{3}$ nanoparticles (The body mass was weighed every other 5 days within the study period).

Effects on number and diameter of follicle. Evaluation of the number of follicles is shown in Table III. There appeared to be no significant relation in number of follicle between Control and /Sham groups $(\mathrm{P}>0.05)$. However, a significant decrease in follicles number was found in dosage $300 \mathrm{mg} / \mathrm{kg}(\mathrm{P}<0.05)$. Similarly, according to Table III, the comparison of the primordial follicle diameters was not significant when experimental groups were compared to Control and Sham groups ( $P>0.05)$. The number of primary follicles in the rats that received 200 and $300 \mathrm{mg} /$ $\mathrm{kg}$ nanoparticle was significantly decreased $(\mathrm{P}<0.05)$ (Table III). Primary follicular diameters showed significant decrease in most groups when compared to the control/ sham groups $(\mathrm{P}<0.05)$. Reduction in the number of secondary follicles was noted in experimental rats compared to the Control and Sham groups $(\mathrm{P}<0.05)$. In addition, secondary follicular diameters were also reduced. The toxicity effects of nanoparticles were also examined in the developmental processes of the ovarian follicle cortex in antral and vesicular ovarian follicles. There was a statistically significant dose-dependent decrease in the number of the follicles, especially for higher doses $(\mathrm{P}<0.05)$. A significant reduction was also observed in the follicular diameters $(\mathrm{P}<0.05)$. The atretic follicles count for the higher-dose rats was significantly increased $(\mathrm{P}<0.05)$ (Table III).

Hormone. Evaluation of ovarian hormone and gonadotropins, indicated that the level of gonadotropin hormones (LH and FSH) was increased after $\mathrm{MoO}_{3} \mathrm{NPs}-$ treatment compared to the Control group $(\mathrm{P}<0.05)$ (Table IV). The statistical analysis of results showed that all doses of $\mathrm{MoO}_{3} \mathrm{NPs}$ significantly increased these hormones in a dose-dependent manner $(\mathrm{P}<0.05)$. The results revealed that estradiol levels in nanoparticle treated groups were significantly decreased compared to control and sham 
Table II. Ovary volume in female rats after 35 days intraperitoneal (IP) administration of $\mathrm{MoO}_{3}$ nanoparticles (mean \pm S.D.)

\begin{tabular}{lcccccc}
\hline & Control & Sham & $50 \mathrm{mg} / \mathrm{kg}$ & $100 \mathrm{mg} / \mathrm{kg}$ & $200 \mathrm{mg} / \mathrm{kg}$ & $300 \mathrm{mg} / \mathrm{kg}$ \\
\hline Cortex volume $\left(\mathrm{mm}^{3}\right)$ & $8.01 \pm 0.75^{\mathrm{a}}$ & $8.04 \pm 0.7^{\mathrm{a}}$ & $6.89 \pm 1.12^{\mathrm{ab}}$ & $6.46 \pm 1.13^{\mathrm{ab}}$ & $5.18 \pm 0.52^{\mathrm{bd}}$ & $3.77 \pm 0.67^{\mathrm{d}}$ \\
Medulla volume $\left(\mathrm{mm}^{3}\right)$ & $2.65 \pm 0.5^{\mathrm{a}}$ & $2.178 \pm 0.81^{\mathrm{a}}$ & $2.37 \pm 0.55^{\mathrm{a}}$ & $1.86 \pm 0.46^{\mathrm{a}}$ & $1.66 \pm 0.51^{\mathrm{b}}$ & $1.26 \pm 0.77^{\mathrm{b}}$ \\
Ovary volume $\left(\mathrm{mm}^{3}\right)$ & $10.71 \pm 0.59^{\mathrm{a}}$ & $10.21 \pm 1.24^{\mathrm{a}}$ & $9.27 \pm 0.81^{\mathrm{ab}}$ & $8.32 \pm 0.97 \mathrm{ab}$ & $6.84 \pm 0.63^{\mathrm{bc}}$ & $5.03 \pm 0.65^{\mathrm{cd}}$ \\
\hline
\end{tabular}

The disparate letters show significant differences $(\mathrm{P}<0.05)$

Table III. Follicle counts and diameter in studied rats after 35-day intraperitoneal administration of $\mathrm{MoO}_{3}$ nanoparticles

\begin{tabular}{|c|c|c|c|c|c|c|c|}
\hline & & Control & Sham & $200 \mathrm{mg} / \mathrm{kg}$ & $100 \mathrm{mg} / \mathrm{kg}$ & $50 \mathrm{mg} / \mathrm{kg}$ & $300 \mathrm{mg} / \mathrm{kg}$ \\
\hline \multirow{2}{*}{$\begin{array}{l}\text { Primordial } \\
\text { follicle }\end{array}$} & Diameter( m) & $22.3 \pm 1.97^{\mathrm{a}}$ & $24.2 \pm 5.3^{\mathrm{a}}$ & $22.5 \pm 3.32 \mathrm{a}$ & $22.3 \pm 3.1^{\mathrm{a}}$ & $22.3 \pm 3^{\mathrm{a}}$ & $23.66 \pm 2.1^{\mathrm{a}}$ \\
\hline & count & $2526 \pm 190.3^{\mathrm{a}}$ & $2599 \pm 183.5 \mathrm{a}$ & $2278 \pm 327.7^{\mathrm{ab}}$ & $2422 \pm 134.5^{\mathrm{a}}$ & $2435 \pm 182^{a}$ & $1938 \pm 237.3^{b}$ \\
\hline \multirow{2}{*}{$\begin{array}{l}\text { Primary } \\
\text { follicle }\end{array}$} & Diameter(_m) & $53.47 \pm 4.6^{\mathrm{a}}$ & $49.65 \pm 1.24 \mathrm{a}$ & $35.4 \pm 2.1^{\mathrm{b}}$ & $36 \pm 6.5^{\mathrm{b}}$ & $33.5 \pm 6.7^{\mathrm{b}}$ & $39.8 \pm 1.7^{\mathrm{b}}$ \\
\hline & count & $1263 \pm 95.1^{\mathrm{a}}$ & $1269 \pm 103.8 \mathrm{a}$ & $990 \pm 156.1^{b}$ & $1050 \pm 118.8^{\mathrm{a}}$ & $1207 \pm 120.5 \mathrm{a}$ & $796 \pm 175^{\mathrm{c}}$ \\
\hline \multirow{2}{*}{$\begin{array}{l}\text { Secondary } \\
\text { follicle }\end{array}$} & Diameter(_m) & $123.3 \pm 35.5^{\mathrm{a}}$ & $102.1 \_12.7 \mathrm{a}$ & $68.6 \pm 15.1^{\mathrm{b}}$ & $79 \pm 3.1^{\mathrm{b}}$ & $72 \pm 8.1^{\mathrm{b}}$ & $85.3 \pm 6.8^{\mathrm{b}}$ \\
\hline & count & $900 \pm 103^{\mathrm{a}}$ & $851 \pm 64^{\mathrm{a}}$ & $389 \pm 89^{d}$ & $493 \pm 129^{c}$ & $723 \pm 43.4^{\mathrm{b}}$ & $348 \pm 75^{d}$ \\
\hline \multirow{2}{*}{$\begin{array}{l}\text { Antral } \\
\text { follicle }\end{array}$} & Diameter(_m) & $308.2 \pm 37.8^{\mathrm{a}}$ & $302 \pm 048.7^{a}$ & $138 \pm 19.3^{\mathrm{c}}$ & $238 \pm 47.5^{\mathrm{b}}$ & $281.8 \pm 102.8^{\mathrm{ab}}$ & $166 \pm 25^{\mathrm{c}}$ \\
\hline & count & $560 \pm 90.4^{\mathrm{a}}$ & $541 \pm 70.9^{\mathrm{a}}$ & $167 \pm 62.5^{\mathrm{c}}$ & $302 \pm 24.8^{\mathrm{b}}$ & $499 \pm 47.9^{\mathrm{a}}$ & $175.16 \pm 28.5^{\mathrm{c}}$ \\
\hline \multirow{2}{*}{$\begin{array}{l}\text { Vesicular } \\
\text { ovarian } \\
\text { follicles }\end{array}$} & Diameter(_m) & $533.5 \pm 53.5^{\mathrm{a}}$ & $498 \pm 47^{\mathrm{a}}$ & $321.9 \pm 64.3^{\mathrm{b}}$ & $445 \pm 88^{\mathrm{a}}$ & $483 \pm 51.4^{\mathrm{a}}$ & $0^{\mathrm{c}}$ \\
\hline & count & $173 \pm 18.2^{\mathrm{a}}$ & $178 \pm 36.4^{\mathrm{a}}$ & $29.5 \pm 21.2^{\mathrm{d}}$ & $76 \pm 34.3^{c}$ & $129 \pm 19.2^{b}$ & $0^{\mathrm{e}}$ \\
\hline Atresia & Diameter(_m) & - & - & - & - & - & - \\
\hline Follicle & count & $35 \pm 20.4^{\mathrm{a}}$ & $30 \pm 13$ a & $139 \pm 28.2^{\mathrm{c}}$ & $84 \pm 8.06^{\mathrm{b}}$ & $34 \pm 8.08^{\mathrm{a}}$ & $234 \pm 44.2^{\mathrm{d}}$ \\
\hline
\end{tabular}

The disparate letters show significant differences $(\mathrm{P}<0.05)$

groups $(\mathrm{P}<0.05)$. This reduction was more pronounced in high dosage treatments. The results also indicated that progesterone serum was significantly increased in the two higher dose of $\mathrm{MoO}_{3}$ NPS group (100 and $300 \mathrm{mg} / \mathrm{kg}$ ) $(\mathrm{P}<0.05)$.In contrast, progesterone level in $200 \mathrm{mg} / \mathrm{kg}$ treated group was decreased however, this reduction was insignificant.

Effects on oocytes volume. Mean comparison of oocyte volume $\left(\mu \mathrm{m}^{3}\right)$ in primordial follicles when Control and Sham were compared to nanoparticles treated groups demonstrated no significant difference $(\mathrm{P}>0.05)$ (Table V). Compared to the control group, the primary oocyte volume in ovary tissues was significantly decreased at higher doses $(100,200,300 \mathrm{mg} / \mathrm{kg})$ of $\mathrm{MoO}_{3} \mathrm{NPs}(\mathrm{P}<0.05)$. Meanwhile, secondary follicles, antral and oocyte volumes were significantly decreased in all doses of the $\mathrm{MoO}_{3}$ NPs treated groups $(\mathrm{P}<0.05)$. Compared to the Control and Sham groups oocyte volume in vesicular ovarian follicles was significantly decreased in the most experimental groups $(\mathrm{P}<0.05)$. It was found that $\mathrm{MoO}_{3}$ nanoparticles affected body weight and similarly significantly suppressed the structure and function of the ovary. Compared to the Control group, average differences of body weights before and after $\mathrm{MoO}_{3}$ NPs-treatment showed a significant decrease $(\mathrm{P}<0.05)$.

Table IV. Measured serum level hormones in studied rats after intraperitoneal (IP) administration of MoO $\mathrm{M}_{3}$ nanoparticles (mean \pm S.D.)

\begin{tabular}{lllllll}
\hline & Control & Sham & $50 \mathrm{mg} / \mathrm{kg}$ & $100 \mathrm{mg} / \mathrm{kg}$ & $200 \mathrm{mg} / \mathrm{kg}$ & $300 \mathrm{mg} / \mathrm{kg}$ \\
\hline FSH $(\mathrm{ng} / \mathrm{mL})$ & $9.27 \pm 6.78^{\mathrm{a}}$ & $28.51 \pm 6.95^{\mathrm{b}}$ & $45.63 \pm 8.59^{\mathrm{c}}$ & $64.16 \pm 14.69^{\mathrm{d}}$ & $83.14 \pm 13.07^{\mathrm{f}}$ & $97.03 \pm 6.69^{\mathrm{f}}$ \\
LH $(\mathrm{mlu} / \mathrm{mu})$ & $18.33 \pm 6.43^{\mathrm{a}}$ & $3.8 \pm 1.76^{\mathrm{b}}$ & $15.18 \pm 5.4^{\mathrm{a}}$ & $26.75 \pm 4.34^{\mathrm{c}}$ & $38.08 \pm 3.27^{\mathrm{d}}$ & $51.4 \pm 2.68^{\mathrm{f}}$ \\
Estrogen $(\mathrm{pg} / \mathrm{mL})$ & $207.2 \pm 108.73^{\mathrm{a}}$ & $121 \pm 78.84^{\mathrm{b}}$ & $65 \pm 27.19^{\mathrm{c}}$ & $88.95 \pm 33.4^{\mathrm{c}}$ & $73.8 \pm 31.08^{\mathrm{c}}$ & $38.43 \pm 1.26^{\mathrm{d}}$ \\
Progesterone $(\mathrm{ng} / \mathrm{mL})$ & $40.95 \pm 15.29^{\mathrm{a}}$ & $45.2 \pm 17.54^{\mathrm{a}}$ & $46.35 \pm 17.5^{\mathrm{a}}$ & $50.18 \pm 9.52^{\mathrm{b}}$ & $35.8 \pm 27.69^{\mathrm{a}}$ & $51.4 \pm 2.68^{\mathrm{b}}$ \\
\hline
\end{tabular}

The disparate letters show significant differences $(\mathrm{P}<0.05)$ 
Table V .Oocytes volume $\left(\mu \mathrm{m}^{3}\right)$ in studied rats after 35-day intraperitoneal administration of $\mathrm{MoO}_{3}$ nanoparticles (mean \pm SD)

\begin{tabular}{|c|c|c|c|c|c|c|}
\hline & Control & Sham & $50 \mathrm{mg} / \mathrm{kg}$ & $100 \mathrm{mg} / \mathrm{kg}$ & $200 \mathrm{mg} / \mathrm{kg}$ & $300 \mathrm{mg} / \mathrm{kg}$ \\
\hline Primordial follicle & $1775 \pm 545.3 \mathrm{a}$ & $1525 \pm 643.2^{\mathrm{a}}$ & $1877 \pm 618^{a}$ & $1646 \pm 653^{a}$ & $1746 \pm 425^{\mathrm{a}}$ & $1445 \pm 636^{\mathrm{a}}$ \\
\hline Primary follicle & $14236 \pm 4493^{\mathrm{a}}$ & $10903 \pm 2532^{\mathrm{a}}$ & $11461 \pm 4724^{\mathrm{a}}$ & $9723 \pm 3771^{\mathrm{b}}$ & $6681 \pm 2888^{b}$ & $7932 \pm 2125^{\mathrm{b}}$ \\
\hline Secondary follicle & $83898 \pm 14259^{a}$ & $90123 \pm 15327^{a}$ & $28555 \pm 15359^{\mathrm{b}}$ & $19703 \pm 2051^{\mathrm{b}}$ & $11962 \pm 7313^{\mathrm{c}}$ & $10231 \pm 3951^{\mathrm{abc}}$ \\
\hline Antral follicle & $135878 \pm 20427^{\mathrm{a}}$ & $156050 \pm 42619^{a}$ & $81032 \pm 34971^{\mathrm{b}}$ & $86658 \pm 40608^{b}$ & $48522 \pm 20181 \mathrm{c}$ & $29624 \pm 8224^{\mathrm{abc}}$ \\
\hline Vesicular ovarian follicles & $249730 \pm 48791^{\mathrm{a}}$ & $215662 \pm 11362^{a}$ & $217579 \pm 89154^{\mathrm{a}}$ & $147731 \pm 52962^{b}$ & $112827 \pm 44284 b$ & $0^{\text {acde }}$ \\
\hline
\end{tabular}

The disparate letters show significant differences $(\mathrm{P}<0.05)$.

\section{DISCUSSION}

The results of present study demonstrated that after the administration of $300 \mathrm{mg} / \mathrm{kg} \mathrm{MoO}_{3} \mathrm{NPs}$, body weight loss was lower than that in the $200 \mathrm{mg} / \mathrm{kg}$ dosage. A possible explanation for these results could be the lower activity of the receptors due to compliance with the toxins when the toxic substances are increased in the body. Another important finding was that ovarian weight was decreased following the administration of $\mathrm{MoO}_{3}$ nanoparticles. It seems possible that these results might be due to: (1) body weight loss which ultimately affected most organs such as the ovary (2) the direct effect of the NPs on the ovaries, and (3) the influence on secretion of the hypothalamic-pituitary-ovary axis. It is well known that body weight and organ weight coefficients are sensitive indicators of potentially toxic chemicals in general toxicity studies (Kim et al., 2007). There are several possible explanations for justifying the reduction in body weight using nanoparticles. The most important factors are decreased absorption, gastrointestinal disorder, loss of appetite or the substantially delayed absorption of food, which indicate that $\mathrm{MoO}_{3}$ nanoparticles influence starving center and reduce appetite of rats to food (ChatterjeeChakrabarty et al., 2005).

In the present study, ovary volumes and follicle numbers were significantly decreased compared to the Control group. This reduction was associated with the ovarian cortex region, the main part of the ovary. This interpretation was also supported by the work of in that the effects of nandrolone decanoate on rat ovaries revealed a reduction in the cortex and medulla volume (KarbalayDoust \& Noorafshan et al., 2012). At the same time, the decreased total number of ovarian follicles in the cortex observed in the $\mathrm{MoO}_{3}$ NPs-treated groups might be due to a decline in the cortex and medulla volumes. Studies of the ovarian structure showed that nandrolone decanoate caused follicle destruction, lack of the corpus luteum and finally a decrease in ovarian volume (Karbalay-Doust \& Noorafshan). Other studies suggested that some nanoparticle scan cause apoptosis and shrink in Granulosa cells (GCs), hence, reducing the weight and size of the ovaries (Ménézo et al., 2011; Foster \& Samman, 2012). In addition a decrease in the mitosis of granulosa cells and theca during folliculogenesis has been observed following the entry of NPs into the body (Asare et al., 2012). The findings of the present study were consistent with those of Braydich-Stolle et al. (2005) who assessed the nontoxicity of $15 \mathrm{~nm}$ silver nanoparticles on male mice. The findings revealed that the apoptosis of cells was dose-dependent and there was reduced mitochondrial function and increased membrane leakage (Braydich-Stolle et al.).

We found that the ovarian volume reduction coincided with the decline in follicle numbers and diameters. On the other hand, no significant differences were observed in the number of primordial follicles compared to the Control group. This result may be explained by the fact that in the present study, $\mathrm{MoO}_{3}$-NPs were administered in the maturation period of rats where primordial follicles were formed in the embryonic period. Although the differences in primordial follicles between the Control group and lower doses was not statistically significant, high levels of $\mathrm{MoO}_{3}$ NPs $(300 \mathrm{mg} / \mathrm{kg}$ ) significantly decreased the number of these follicles, which showed the toxic effects of $\mathrm{MoO}_{3}-\mathrm{NPs}$ on primordial follicles at the highest dose. This finding suggested that ovarian follicles were one of the major targets of $\mathrm{MoO}_{3}$ in rats at elevated doses. Moreover, no significant change was observed in the primordial follicular diameter compared to the control group, owing to the fact that they are shaped in the embryonic period of some mammalian species with a specific number and diameter according to their genetics, consisting of oocytes and a layer of simple squamous cells. The present study showed that there was a highly significant decrease in the number of primary follicles of rats after administration of molybdenum oxide nanoparticles with middle $(200 \mathrm{mg} / \mathrm{kg})$ and high-doses $(300$ $\mathrm{mg} / \mathrm{kg}$ ) when compared to the Control group. It seems possible that the presence of toxic substances could affect the transition of primordial follicles into primary follicles and their evolution. As a consequence, primordial follicles 
are unable to pass their natural course of development and thus the number of primary follicles at higher doses is significantly decreased. Furthermore, reduction in the number of primary follicles could be attributed to the effect of $\mathrm{MoO}_{3}$ nanoparticles on folliculogenesis which in turn suppresses growth factors that play an important role in gonad development. In addition, the suppression of activator or inhibitor factors and/or dysregulation in feedback cycles of the gonads and brain might occur following $\mathrm{MoO}_{3}$-NPs administration. Considering oocyte volume reduction, it could be concluded that the impairment of oocyte growth and beta family factors and the final destruction of granulosa cells are impressed by $\mathrm{MoO}_{3}$-NPs administration (Himelstein-Braw et al., 1976). Studies have also shown that the primordial transition to primary follicles can be associated with the cross-interaction of oocytes, granulosa and theca cells. Moreover, oocyte growth factor (GDF-9) has a central role in folliculogenesis and ovulation (Omidi et al., 2015).

Thus, in the present study, $\mathrm{MoO}_{3}$ might inhibit and reduce the expression of GDF-9 which subsequently suppressed folliculogenesis and primary follicular growth. Taken together, a reduction in primordial follicle evolution to primary follicles is probable. This impact can be seen in all stages of follicle development as a sharp decline in Graafian follicles observed in the $300 \mathrm{mg} / \mathrm{kg}$-treated group. In a study that examined the effect of sodium arsenite on ovarian follicles, it was found that ovarian volume in varieties of follicles such as primary, secondary, antral and Graafian, were significantly decreased compared to the control groups, which showed a further decline in oocyte development and sizes (Mehranjani et al., 2010). In the present study, a direct association between the follicular diameters and ovarian volume was found in different treated groups. A possible explanation for these results may be due to the fact that ovarian cortex volume, and therefore total volume of the ovary were the main contributor to follicle size and number. Reducing the follicle diameter decreases the size of the ovarian cortex which ultimately affects the whole of the ovary. On the other hand, the evolutionary process of follicles is controlled by hypothalamic-pituitary-ovary axis secretion. Therefore, the secretion of this axis also changes the development of follicles. Thus, follicle development may be affected by the impact of nanoparticles during follicle evolution. These follicles are formed in various stages of sexual cycles of mammals and their formation can be affected by different substances (Güney et al., 2007).

The results of the present study showed that gonadotropin levels (FSH and LH) in experimental groups were increased significantly in a dose-dependent manner in comparison with the control group. It is widely accepted that an increase in FSH leads to the elevation of oestrogen levels, however, a significant decrease in the estrogen hormone was observed in the $\mathrm{MoO}_{3}$-NPs-treated groups in the present study. Therefore, it is likely that $\mathrm{MoO}_{3} \mathrm{NPs}$ impeded the FSH function which naturally increases follicular growth and subsequent estrogen secretion. Elevation in FSH level can be the result of nanoparticle effects on the hypothalamic-pituitary-ovarian (HPO) axis which subsequently increase GnRH secretion, stimulating the pituitary. The releasing hormones induce the production and secretion of gonadotropins (i.e., LH and FSH), which in turn are transported by the blood to the gonads (i.e., the ovaries) (Ogasawara et al., 2008).

In general, $\mathrm{MoO}_{3}-\mathrm{NPs}$ exhibited the greatest influence on the hypothalamus and increased $\mathrm{GnRH}$ secretion, which was responsible for increasing the FSH level and promoting estrogen production. However, this rather contradictory result found in our study regarding estrogen level may be due to (1) the direct impact of nanoparticles on the ovaries, which further suppressed follicular growth and reduced oestrogen, or (2) interference with the normal functioning of follicles. Therefore, the number of estrogen secreting follicles was decreased, resulting in reduced estrogen secretion. The results of the present study demonstrated that Ni NPs increased the level of serum FSH and decreased estrogen associated with a significant and dose-dependent manner in rats. Another possible explanation for this is that follicular granulose cells that sprinkle estrogen were dispersed. According to the Kong et al., results, they showed that oestrogen and progesterone hormone synthesis were associated with smooth reticulum endoplasmic. Their findings supported the idea of toxicological effects of nickel nanoparticles on the female reproductive system, using scanning electron microscopy, in which slight swelling, cavitation, and crest disorders of the mitochondria were observed in primary follicles dosed with $15 \mathrm{mg} / \mathrm{kg} \mathrm{BW}$. The authors concluded that oxidative stress and cell apoptosis may play important roles in inducing reproductive toxicity after Ni NPs treatment (Kong et al., 2016).

An implication of this idea was the possibility that apoptosis led to cell death and ovary lesions in our research. Hence, $\mathrm{MoO}_{3}$ nanoparticles affected the functions of the mitochondria and smooth endoplasmic reticulum, finally reducing estrogen synthesis. All doses of $\mathrm{MoO}_{3} \mathrm{NPs}$ significantly increased LH which in turn induced progesterone production. These changes might be due to the follicles that reached developmental stages (turn into the corpus luteum) and continued to undergo progesterone secretion. In addition, the hormonal arrangement between 
the ovary and gonadotropins was disturbed, therefore the arrangement between the brain-ovary and pituitary was changed. The results of the present study could be compared to the findings of previous works that reported the impacts of chemicals on the ovaries and brain-pituitaryovary axis, as well as sex hormonal secretion (Meller et al., 2001). In the present study, $\mathrm{MoO}_{3} \mathrm{NPs}$ increased progesterone levels, while LH level was also remained high at the same time. Thus, consistent with others, we speculated the abnormal brain-pituitary-ovarian excretion that eventually causes infertility (Kong et al., 2016).

In summary, the findings of the present study indicated that $\mathrm{MoO}_{3}$ NPs could be considered as ovary toxicants. It could be concluded that $\mathrm{MoO}_{3}$ NPs broke the balance between gonadotropins and estrogen secretion. These effects further changed normal evolutionary trend and reduced follicle numbers, which in turn reduced ovary volumes.

Abbreviations: IP: intraperitoneal, NPs: nanoparticles, CB: carbon block, TEM: Transmission Electron Microscopy, XRD: X-ray diffraction measurements, SEM: Scanning Electron Microscope,GCs: Granulosa cells, IUR: Isotropic uniform random, HPO: hypothalamic-pituitary- ovarian.

ETHICS STATEMENT. All experiments on mice has been reviewed and approved by the institutional animal care No IR.Iau.tmu.REC.1395.24.

ASADI, F.; FAZELIPOUR, S.; ABBASI, R. H.; JAHANGIRIRAD, M.; TOOTIAN, Z.; NEDAEE, K. \& FAZELIPOUR, M. Evaluación de folículos ováricos y hormonas reproductivas en suero de ratas tratatas con nanopartículas de trióxido de molibdeno. Int. J. Morphol., 35(4):1473-1481, 2017.

RESUMEN: Las características específicas de las nanopartículas han dado lugar a su uso generalizado. Las pequeñas nanopartículas de trióxido de molibdeno $\left(\mathrm{MoO}_{3}\right)$ pueden penetrar los sistemas circulatorios y linfáticos y, en última instancia, dependiendo de su composición y tamaño, también los tejidos y órganos del cuerpo. En esta investigación se dividieron 60 ratas Wistar con un peso de 180-250 g en 6 grupos $(n=10)$ aleatoriamente: el Grupo 1 (Control) no recibió ningún medicamento. El Grupo 2 (Sham) recibió solución salina normal intraperitoneal durante 35 días diariamente. Los grupos 3, 4, 5 y 6 recibieron 50, 100, 200 y $300 \mathrm{mg} / \mathrm{kg}$ de $\mathrm{MoO}_{3}$ respectivamente, de la misma manera en el grupo simulado, y en el mismo intervalo. Concluyendo el experimento, las ratas se pesaron nuevamente y fueron anestesiadas. Luego se tomaron muestras de sangre de los corazones para determinar los niveles séricos de estrógeno, progesterona y gonadotropinas. Se retiraron los ovarios y se determinó el volumen ovárico, el diámetro folicular, el número de cada tipo de folículo y el volumen de ovocitos. Los resultados indicaron que las nanopartículas de $\mathrm{MoO}_{3}$ redujeron significativamente los pesos corporal y ovárico en las ratas. Además, se observó una disminución importante en el volumen ovárico, el número de tipos de folículos, el volumen de ovocitos y el diámetro folicular. Las nanopartículas aumentaron el número de folículos auriculares a través de la estructura del tejido ovárico. Las nanopartículas de $\mathrm{MoO}_{3}$ disminuyeron el nivel sérico de estrógeno y aumentaron el nivel sérico de FSH que se asoció con la interrupción en la regulación de la progesterona y la secreción de LH. Los hallazgos mostraron que las nanopartículas de $\mathrm{MoO}_{3}$ podrían tener efectos negativos sobre la estructura y la función ovárica.

PALABRAS CLAVE: Nanopartículas de trióxido de molibdeno; Ovario; Estereología; Hormonas reproductivas; Ratas.

\section{REFERENCES}

Adams, L. K.; Lyon, D. Y. \& Alvarez, P. J. Comparative eco-toxicity of nanoscale $\mathrm{TiO} 2, \mathrm{SiO} 2$, and $\mathrm{ZnO}$ water suspensions. Water Res., 40(19):3527-32, 2006

Armenti, A. E.; Zama, A. M.; Passantino, L. \& Uzumcu, M. Developmental methoxychlor exposure affects multiple reproductive parameters and ovarian folliculogenesis and gene expression in adult rats. Toxicol. Appl. Pharmacol., 233(2):286-96, 2008.

Asare, N.; Instanes, C.; Sandberg, W. J.; Refsnes, M.; Schwarze, P.; Kruszewski, M. \& Brunborg, G. Cytotoxic and genotoxic effects of silver nanoparticles in testicular cells. Toxicology, 291(1-3):65-72, 2012.

Bakand, S. \& Hayes, A. Toxicological considerations, toxicity assessment, and risk management of inhaled nanoparticles. Int. J. Mol. Sci., 17(6):E929, 2016.

Braydich-Stolle, L.; Hussain, S.; Schlager, J. J. \& Hofmann, M. C. In vitro cytotoxicity of nanoparticles in mammalian germline stem cells. Toxicol. Sci., 88(2):412-9, 2005.

Chatterjee-Chakrabarty, S.; Miller, B. T.; Collins, T. J. \& Nagamani, M. Adverse effects of methylphenidate on the reproductive axis of adolescent female rats. Fertil. Steril., 84 Suppl. 2:1131-8, 2005.

Ferreira, F. F.; Cruz, T.; Fantini, M. C. A.; Tabacniks, M. H.; de Castro, S. C.; Morais, J.; De Siervo, A.; Landers, R. \& Lourenco, A. Lithium insertion and electrochromism in polycrystalline molybdenum oxide films. Solid State Ion., 136:357-63, 2000.

Foster, M. \& Samman, S. Zinc and regulation of inflammatory cytokines: implications for cardiometabolic disease. Nutrients, 4(7):676-94, 2012.

Güney, M.; Demirin, H.; Oral, B.; Ozgüner, M.; Bayhan, G. \& Altuntas, I. Ovarian toxicity in rats caused by methidathion and ameliorating effect of vitamins E and C. Hum. Exp. Toxicol., 26(6):491-8, 2007.

Hillier, S. G. Current concepts of the roles of follicle stimulating hormone and luteinizing hormone in folliculogenesis. Hum. Reprod., 9(2):188$91,1994$.

Himelstein-Braw, R.; Byskov, A. G.; Peters, H. \& Faber, M. Follicular atresia in the infant human ovary. J. Reprod. Fertil., 46(1):55-9, 1976.

Karbalay-Doust, S. \& Noorafshan, A. Stereological estimation of ovarian oocyte volume, surface area and number: application on mice treated with nandrolone decanoate. Folia Histochem. Cytobiol., 50(2):2759, 2012.

Kim, H. Y.; Lee, S. B.; Lim, K. T.; Kim, M. K. \& Kim, J. C. Subchronic inhalation toxicity study of 1,3-dichloro-2-propanol in rats. Ann. Occup. Hyg., 51(7):633-43, 2007. 
ASADI, F.; FAZELIPOUR, S.; ABBASI, R. H.; JAHANGIRIRAD, M.; TOOTIAN, Z.; NEDAEI, K. \& FAZELIPOUR, M. Assessment of ovarian follicles and serum reproductive hormones in molybdenum trioxide nanoparticles treated rats. Int. J. Morphol., 35(4):1473-1481, 2017.

Mehranjani, M. S.; Noorafshan, A.; Hamta, A.; Momeni, H. R., Abnosi, M. H., Mahmoodi, M.; Anvari, M. \& Hazaveh, M. Effects of vitamin E on ovarian tissue of rats following treatment with p-nonylphenol: A stereological study. Iran. J. Reprod. Med., 8(1):1-9, 2010.

Meller, W. H.; Grambsch, P. L.; Bingham, C. \& Tagatz, G. E. Hypothalamic pituitary gonadal axis dysregulation in depressed women. Psychoneuroendocrinology, 26(3):253-9, 2001.

Ménézo, Y.; Pluntz, L.; Chouteau, J.; Gurgan, T.; Demirol, A.; Dalleac, A. \& Benkhalifa, M. Zinc concentrations in serum and follicular fluid during ovarian stimulation and expression of $\mathrm{Zn}^{2+}$ transporters in human oocytes and cumulus cells. Reprod. Biomed. Online, 22(6):647-52, 2011

Ogasawara, H.; Ohwada, S.; Nagai, Y.; Taketa, Y.; Matsuzaki, M.; Tanaka, S.; Watanabe, K.; Aso, H. \& Yamaguchi, T. Localization of leptin and leptin receptor in the bovine adenohypophysis. Domest. Anim. Endocrinol., 35(1):8-15, 2008.

Omidi, S.; Negahdary, M. \& Aghababa, H. The effects of zirconium oxide nanoparticles on FSH, LH and testosterone hormones in female Wistar rats. Electron. J. Biol., 11(2):46-51, 2015.

Shoults-Wilson, W. A.; Reinsch, B. C.; Tsyusko, O. V.; Bertsch, P. M.; Lowry, G. V. \& Unrine, J. M. Effect of silver nanoparticle surface coating on bioaccumulation and reproductive toxicity in earthworms (Eisenia fetida). Nanotoxicology, 5(3):432-44, 2011.

Tsuchiya, T.; Oguri, I.; Yamakoshi, Y. N. \& Miyata, N. Novel harmful effects of fullerene on mouse embryos in vitro and in vivo. F. E. B.S. Lett., 393(1):139-45, 1996.

Wang, J.; Zhu, X.; Zhang, X.; Zhao, Z.; Liu, H.; George, R.; WilsonRawls, J.; Chang, Y. \& Chen, Y. Disruption of zebrafish (Danio rerio) reproduction upon chronic exposure to $\mathrm{TiO}$ nanoparticles. Chemosphere, 83(4):461-7, 2011.

Zollfrank, C.; Gutbrod, K., Wechsler, P. \& Guggenbichler, J. P. Antimicrobial activity of transition metal acid $\mathrm{MoO}_{3}$ prevents microbial growth on material surfaces. Mater. Sci. Eng., 32:47-54, 2012.

\author{
Corresponding author: \\ Simin Fazelipour, PhD \\ Anatomy professor \\ Medical Sciences Branch \\ Islamic Azad University \\ Tehran \\ IRAN
}

Email: sfazelipur@iautmu.ac.ir simin_fazelipour@yahoo.com

Received: 07-06-2017

Accepted: 31-07-2017 